\title{
Studies of Irritability in Plants .
}

\author{
BY \\ GEORGE J. PEIRCE. \\ Associate Professor of Plant Physiology in the Leland Stanford Junior University.
}

The Formative Influence of Light.

With Plate XXXV.

I. INTRODUCTION.

$A^{S}$ my experiments were abruptly terminated by the earthquake of A April I 8, it seems on some accounts desirable to record and partly to discuss the results I already have, rather than wait until I can report more. These experiments have been repeated, most of them many times, always with the same results, and I shall go on in the lines which this paper suggests as soon as circumstances permit. The statements of fact I make with no hesitation; the interpretation of these facts I offer subject to such modification as my further work may make necessary. Yet I cannot help feeling that I have gone far enough to justify positive conclusions so far as two species of plants are concerned, and to suggest the reasonableness of the inference that the conditions are not fundamentally different with a considerable number of others.

In 1898 Czapek ${ }^{2}$ reported: "Wenn man Brutkörper von Marchantia auf feuchtem Substrat am Lichte . . . auf dem Klinostaten auskeimen lässt, so entstehen im Laufe von 2-3 Monaten kleine schwächliche Pflänzchen, welche aus röhrig zusammengeschlossenen Thalluslappen bestehen, und rings Wurzeln tragen ... Dieser interessante Versuch

1 The first paper in this series-Studies of Irritability in Algae, Botanical Gazette, 40, Nov., 1905-was published by Miss Flora A. Randolph and myself. The work of the present paper has been done either by myself alone or, under my direction, by two students, Miss Cora A. Snyder and Miss Clara A. Tompkins. I assume the responsibility for what I here say, however, for I cannot submit this paper to my sometime collaborators, and I have carried the work further than either of them knows. I wish also to acknowledge the careful help of Mr. R. M. Holman, now Assistant in Botany in this University.

${ }^{2}$ Czapek, F., Weitere Beiträge z. Kenntniss der geotropischen Reizbewegungen. Jahrb. fow. Bot., xxii, 26r, 1898.

[Annals of Botany, Vol, XX. No. LXXX. October, 1906.] 
lässt sich leider nicht über 2-3 Monate hinaus fortsetzen, weil die Pflänzchen auf einer kleinen Anheftungsstelle senkrecht auf dem Substrate aufsitzend naturgemäss schlecht mit Wasser und mineralischen Nährsalzen versorgt werden, und auch die Befestigung eine mangelhafte ist. Es lässt sich aber doch erweisen, dass die Dorsiventralität auf dem Klinostaten nicht zu Stande kommt.'

This interesting experiment, in which the very marked and longknown dorsi-ventrality of Marchantia failed to appear, suggested to me that possibly less imperfect plants, with the same radial structure, might be developed if, instead of beginning with multicellular and comparatively large reproductive bodies like gemmae, spores were used. Furthermore, gemmae are subject to the influence of light, mainly from one direction, during the course of their development on the surface of the thallus. Spores are also more or less illuminated, but only through the surrounding tissues of the sporophyte. Gemmae must develop at once, if at all, and there is no possibility of allowing the effect, if there be any, of light to pass off before they are sown. Spores can be kept for weeks or months in perfect darkness, and the following experiments will show that, in most cases at least, there is not the slightest evidence that they are permanently influenced by the light which filters through overlying tissues upon them.

Although Marchantia grows and fruits in the mountains not far from here, it is not easily accessible, and does not fruit at a season when one can conveniently sow the spores. That the spores may be kept as long as other Liverworts growing in dryer places I doubt. These other Liverworts-for example, Fimbriaria Californica (Asterella), and species of Anthoceros, \&c.- and such Ferns as Gymnogramme triangularis, are abundant, and their spores may be collected in quantity, and sown when convenient.

The great difficulty is in getting clinostats. A good clinostat is expensive, and few American laboratories can afford more than one or two good ones. Following Ganong's directions ${ }^{1}$, I had ten eight-day clocks, of the alarm-clock shape but without alarms, cut down so that they ran at four times the speed, removed the hands, and put flat plates on the minute-hand spindles. These clocks therefore give cultures a revolution completed every fifteen minutes. In addition to these eight-day clocks, I had twelve one-day clocks ('dollar clocks'), similarly fitted with plates carried on the minute-hand spindles. These clocks complete in one hour the revolution of a culture carried on the plate. By using clocks of these two speeds, I was led to believe that had Czapek used a faster clinostat he would have succeeded in getting, not folded, but solid cylindrical plants. I will discuss this point later, however. The mere mechanical labour of winding twelve clocks every day, and twenty-two clocks every other day

\footnotetext{
${ }^{1}$ Ganong, W. F., A laboratory course in Plant Physiology, pp. I 20-I, New York, I9or.
} 
for nine months, is tiresome, and I shall in the future use one motive power for as many cultures as possible. Furthermore, no spring clock is absolutely reliable, and though these cheap clocks have served me well enough to enable me to reach certain results, they are not suitable for experiments lasting months at a time. I have lost many cultures because clocks have suddenly stopped which had carried them regularly for months. The loss of time from this cause is often very great. I am now working on a motor which I hope will be both efficient and reliable, and at the same time require less frequent winding.

I began my experiments on Liverworts and Ferns by using small flower-pot saucers of soft porous red clay. These, when used in pairs (the upper saucer containing soil, the lower filled with water), have the great advantage of furnishing well-drained culture dishes. On the other hand, being opaque, they cast a shadow over a greater or less proportion of the surface of the culture. For this reason, I have now used for some time crystallizing dishes of thin white glass, about eight centimetres in diameter and three and a half centimetres deep, covered with the lids or bottoms of Petri dishes. These lids, not fitting tightly, permit fair ventilation, at the same time that they exclude dust and retain moisture. Dull black paper is finally glued over the tops of the lids, so that all light falls nearly or quite horizontally.

The soil used came from the surface of the banks where the Liverworts and Ferns grew from which I collected the spores. The soil was air-dried, freed from pebbles, pulverized in a mortar, and filled into the dishes to the depth of about a centimetre. The soil was moistened from the start with boiled distilled water only, for I wished to avoid an accumulation of salts from our hard tap-water in these undrained dishes. I have not attempted to supply equal quantities of water to the cultures, though I have taken pains to give no excess, and to water fairly uniformly. When the antheridia and archegonia of Anthoceros and Gymnogramme were ripe, I watered abundantly once or twice, and, a few days after, poured off the excess. Thus I ensured swimming room for the antherozoids, and presently the sporophytes of both began to appear.

In experiments on Anthoceros two sets of cultures were used, on sterilized and on unsterilized soil, for both species of Anthoceros common here (A. fusiformis, Aust., and A. Pearsoni, M. A. Howe) contain colonies of Nostoc (sp.?). I have elsewhere reported ${ }^{1}$, however, that Anthoceros appears to grow better, and in other respects perfectly normally, without Nostoc, and for this reason it is quite fair to use only sterilized soil. The dishes, containing the duly moistened soil and covered, were sterilized on three successive days in an Arnold steam sterilizer, the last sterilization lasting several hours. Though subsequent fungous infections cannot

1 Peirce, G. J., Anthoceros and its Nostoc colonies, Bot. Gazette, xlịi, July, Igo6. 
always be avoided, and though there may be other spores introduced than those designed, such sterilization as this is efficient in destroying whatever was in the soil and the water at the start.

As I wished to study the early stages in germination, I made a few cultures under somewhat different conditions. I placed a sheet of white filter paper over the moist soil before sterilizing, and afterwards enclosed the dishes in dull opaque black paper except for a slit on one side, one centimetre square, and reaching upwards from the top of the layer of soil. Thus whatever light entered these dishes entered from one direction only, with the rays mainly parallel.

In another case I used Knop's solution, sterilizing as before, placing an equal number of cultures on clinostats and on the shelves beside them.

While in Naples in I904 I began experimenting similarly with marine algae, and I have had no opportunity as yet to resume experimental work on sea-weeds, though I hope to do so presently. I will report such results as I obtained for whatever suggestive value they may have.

Uniform sowing of spores on prepared surfaces-soil, paper, or wateris not easy, and as the young plants growing up close together shade each other, it is very important that the spores be sown sparingly, and be as uniformly distributed as possible. I have tried to dust them carefully from paper held at some distance above the dishes. By turning the dishes at the same time, some degree of uniformity in distribution is attainable, especially if only a small quantity of spores be used for each dish.

By using dishes no deeper than the crystallizing dishes described, it is possible to place them on the stage of an ordinary microscope, and to examine them without in any way disturbing the cultures. It is necessary to make the camera drawings of clinostat cultures as rapidly as possible, to avoid too long exposure to light from one direction only. The exposure to the comparatively dry air of the laboratory for such short times, say five minutes, seems not to injure the plants, for I have taken pains not to keep the cultures very wet. Where it is necessary to make more careful or more detailed drawings, the only thing to do is to remove the little plant to be studied from the culture altogether, and this means its loss; but I have made many rapid drawings in succeeding weeks of the same plants as they were growing, and in this way I have been able to follow the development of the same individuals.

The cultures were all on shelves in windows facing south-west. Direct sunshine was avoided by window-shades of thin white holland, drawn up from below when needed. The temperature of the laboratory naturally ranged somewhat higher than that out of doors; but it was, nevertheless, not so high by day as that of most American laboratories, artificially heated in winter, and at night it was not so low as out of doors. The result this year was a much more rapid and luxuriant growth in my cultures than 
out of doors. This was due largely to the dry and cold November and December, during which out-of-door plants grew but little.

2. The Influence of Light upon Germination and Early Growth.

The germination of the spores of various archegoniates has been repeatedly described in monographs and in larger works ${ }^{1}$, and the development of these plants has been studied by many plant physiologists, but I was interested to compare the early stages of germination and growth, with reference to the influence of light, with the behaviour of germinating algal spores, as described by Rosenvinge, Winkler, and myself $^{2}$. To do so, I sowed the spores of $A$. fusiformis, Fimbriaria Californica, and Gymnogramme triangularis, which I had collected when ripe during the season of 1905 , on white filter-paper over damp soil, in covered crystallizing dishes enclosed in black paper. On the side next the window I cut a hole I centimetre square in the black paper. The sowing was on March 29. On April I 2 I found the first young plants of $A$. fusiformis, two weeks after sowing. These are shown in Pl. XXXV, Fig. I. The arrow indicates the direction of light. In this culture the sowing was not uniform, and there was more or less shading of adjacent spores by each other; yet, with the apparent but not real exception of the two plants $a$ and $b$, which were shaded (the shading neighbour of $a$ is not shown), all were not only growing toward the light, but their first division walls were, like those of the algae previously referred to, at right angles to the incident rays. We have here, then, photaxis of the germ-tube, and the determination of the angle of division by the direction of illumination. The influence of light on germination is indicated by the fact that at 3 centimetres away from the opening in the black paper there were no germinations; at 2.4 centimetres, one; at 2 centimetres there were ten; at I. 5 centimetres, twenty-five; and from there on there were too many to count. From this statement, and from Fig. I, we see, in the first place, that germination itself is dependent upon a certain though undetermined amount of light; and, in the second place, that the direction of growth, and of the successive cell divisions, is determined by the direction of light.

Fig. 2 represents a Fimbriaria spore germinating thirteen days after sowing, the arrow, as before, indicating the direction of the incident light. This figure shows that the direction of growth of the germ-tube and of the first division walls is determined by the direction of the light. It may be objected that the division walls are laid down at right angles to the long axis of the germ-tube, and not at right angles to the incident rays. This

${ }^{1}$ For example Campbell, D. H., Mosses and Ferns, 2nd edition, I905.

${ }^{2}$ Rosenvinge, L. K., Influence d'agents extérieurs sur l'organisation polaire et dorsiventrale des plantes, Revue génér. de Bot., i, 1889. Winkler, H., Einfluss äusserer Factoren auf die Theilung der Eier von Cystoseira barbata, Ber. d. Deutsch. Bot. Ges., xviii, I900. Peirce and Randolph, loc. cit. 
is true; but it is the direction of the light that determines the direction of the long axis of the germ-tube. By so doing it affects the plane of division, indirectly if not directly. In any case, it is extremely probable that what appears to be very directly the result of light action, is rather the end result of a long series of reactions, only the first one of which was due directly to the influence of light.

In Fig. 3 is shown a group of two Fimbriaria spores, as they were at 2.I5 p.m. on the thirteenth day after sowing. The rhizoid formed by one of the little plants had grown out from the side of the plantlet away from the light, and was already bending toward the darker part of the culture. The same plantlets at II.I5 a.m. the next day are shown in Fig. 4. At this time the rhizoid was growing still more markedly away from the light, in spite of the fact that for more than half of the time which had intervened between the two sketches the plants were in darkness, or in extremely feeble light. Fig. 5 shows a plantlet, in which the third and fourth division walls, as well as the first and second, are nearly at right angles to the direction of light. The opaque spore shut off a certain amount of light, and hence the direction of the first wall, parallel with the general direction of the rays, is really at right angles to the rays actually reaching the germ-tube. The figure shows, furthermore, that the rhizoid, as in sessile algae, develops on the darker side.

Although in many cases-in fact, the majority-the spore puts out the germ-tube on the side toward the light, it does not invariably do so. Perhaps this is due to the effect of light upon the spore as it matured in the tissues of the sporophyte. But the spores which send out a germ-tube in other directions than toward the light are relatively so few that I cannot believe this to be the case. Perhaps there is such a thing as polarity in these spores, but, if so, the manner of collecting and sowing the spores should result in a much more general distribution of their poles; their germ-tubes should not originate mainly on any one side, whether toward the light or in any other direction.

Fig. 6 indicates the direction of growth and division of the germ-tubes of Gymnogramme, the spores of which I had sown on February 23, and which had been almost continuously illuminated by incandescent electric lights for five weeks. The slowness of germination may have been due to various causes; but the most evident of the possible influences affecting germination was the intensity of the light. For twenty-five days I lighted the cultures by 4-candle power bulbs. Finding such slight evidence of germination at this time, I changed to 8-candle power frosted bulbs, and at the end of three days to I6-candle power clear bulbs. At the end of six days very many fern spores were germinating. The temperature in the box in which lights and cultures were, was about that of the room for the first twenty-five days, and went up to about $32^{\circ} \mathrm{C}$. when 
I put in the I6-candle power lights. This may have accelerated germination ; but the experiment, except as indicating that the direction of growth and of cell-divisions in the germ-tubes of this Fern is influenced by light, even of composition so different from sunlight, was of little value. A repetition of the experiment was interrupted by the earthquake of April I8.

It is conceivable that in all of these cases the side from which the spore puts out the germ-tube, the direction of growth of the germ-tube, and the side of it on which the first rhizoid appears, may be the sides or the direction most free from the mechanical pressure or resistance of particles of soil or of raised spots in the filter-paper on which the spores were sown. To avoid this objection, I sowed spores of Gymnogramme on the surface of a filtered Knop's solution in two covered crystallizing dishes. Black paper was glued to the covers, so that light reached the spores only through the sides of the dishes. One dish I placed on a clock-clinostat, making a complete revolution every quarter-hour; the other dish was on the shelf three inches above. Fig. 7 shows two young Ferns, sixteen days after the spores were sown in the dish on the shelf. The light fell in the direction indicated by the arrows. The germ-tubes are growing toward the window, the first division walls are at right angles to the incident rays, and the rhizoids appear on the dark side of the young plants. Fig. 8 is a diagram in which is indicated by arrows the direction of the germ-tubes of the spores germinating on the Knop's solution in the dish upon the clinostat. The age is the same, all the conditions were the same for the two cultures except that in this culture the light entered through all sides successively as the dish was revolved. The direction of growth of the rhizoids was as various as that of the germ-tubes, generally, however, opposite to that of the germ-tube. These two cultures show plainly, therefore, that it is the direction of illumination, and not any mechanical resistance, which determines the direction of growth of the germ-tube and of the first divisions of its cells, and that ordinarily the rhizoids spring from the shaded side of a plantlet, and grow away from the light.

Thus we see that, in respect to their relations to light as an influence directing growth, the spores of these archegoniates behave similarly to the spores of the algae previously described. The advantage is obvious : the germ-tube grows where light will enable the young plant to make food for itself; the rhizoid grows where it can form an attachment for the young plant. At this stage at least, water and food materials are absorbed through all parts of the plant-body; the main function of the rhizoid is to fasten the plant to the soil, and, by giving it suitable mechanical support, enable it to continue the growth of the green parts in the most advantageous direction. This is probably the main function of the rhizoid throughout the lifetime of these small plants; but it may not be the sole function. 


\section{Description of the Influence of the Direction of LIGHT UPON FORM.}

Spores of Anthoceros fusiformis were sown on damp soil in the blacktopped crystallizing dishes previously described, some on clinostats, some on the shelf a few inches above them. The sowings were made on November I. The clinostats made a complete revolution once in fifteen minutes, and were constantly in motion, by night as well as by day. The laboratory was dark between sunset and sunrise. Seven weeks, less one day, after sowing I made the drawing reproduced as Fig. 9. This represents a young plant taken out of the culture and placed in part profile in a drop of water on a slide. The general shape of the plant is that of a vase, with a flaring concave top, lobed in outline, borne on a solid base tapering to the bottom. From all sides of the base rhizoids grow in various directions. The soil on which this plant grew was not sterilized, and the plant contained one Nostoc colony of normal size and appearance. If this figure be compared with Figs. Io and Io a, representing a plant growing in a dish on the shelf immediately above the clinostat, but otherwise under as nearly as possible identical conditions, it becomes evident that there are decided differences. Fig. IO $a$ is an optical section of the plant drawn from above in Fig. Io. These drawings show a lobed plant expanded at right angles to the light (the arrow indicates the direction from which the light comes) and bearing rhizoids on the shaded side only. This is the usual form of the ordinary young plant of $A$. fusiformis whether grown in culture or found out of doors. The position of the plant is unusual in one respect; it is nearly vertical to the surface of the soil instead of being more or less closely appressed to it. The reason is that the light falls upon the culture in a direction nearly parallel to the surface of the soil, whereas out of doors the light usually falls at nearly a right angle to the surface. The position of the plants out of doors and in cultures is the same in relation to the light-the dominant influence-namely at right angles to it. The direction of the surface of the soil exerts no influence on the direction of growth except as it ordinarily determines the direction from which the light comes.

Corresponding with the results indicated by the foregoing figures of $A$. fusiformis are the results of sowings of spores of $A$. Pearsoni, one set in dishes revolving on clocks and the other in dishes unmoved on the shelf three inches above. Figs. II and I $a$ show plants six weeks, less one day, after sowing. The clock was a slow one, making a complete revolution once an hour. In spite of this rate of revolution, one quarter as fast as that of the clock carrying the plant of A. fusiformis shown in Fig. 9, these plants of $A$. Pearsoni (Fig. II) are solid, conical, not rolled or flat, flaring and lobed at the top, and having rhizoids all around their cylindrical bases. The little plant from a culture on the shelf and shown in Fig. I $a$ is in very 
sharp contrast to these, being flat and expanded at right angles to the incident rays of light, and having rhizoids on the shaded side only.

Similar cultures of Fimbriaria Californica are shown in Figs. I2 and $\mathrm{I} 2 a$. Fig. 12 shows plants growing on a quick clock, revolving completely four times an hour, and drawn five weeks and one day after sowing. These plants are solid, erect, with conical more or less lobed and concave tops borne on cylindrical bases, from all sides of which rhizoids spring. Fig. I $2 a$ shows a shelf plant of the same age, with the ordinary form, expanding at right angles to the light, and with rhizoids only on the shaded side. Fig. 13 shows a plant midway between Figs. 12 and $12 a$ in form. This plant grew on a slow clock, making only one revolution per hour. The plant was drawn five weeks and a half after sowing. The plant is going over from the vasiform to the usual flattened thallus. This change is completed a little later. Indeed on all my clocks, fast or slow, Fimbriaria plants lose their early cylindrical form sooner or later. Whether grown on clocks or shelves these plants are all cylindrical at first. The only difference made by my clocks is to defer the period of flattening. The clocks defer this for a longer or shorter time according to their speed, the faster the clock the more perfectly round the plant and the longer it will remain so. I have as yet no means of revolving cultures more rapidly than four times an hour, but I hope to have on resuming these experiments next September.

Cultures of Gymnogramme triangularis five weeks and a day after sowing are shown in Figs. I4 and I4 $\alpha$. Although spores were sown in a culture on a quick clock, the young prothalli of this fern did not remain cylindrical in form beyond the very early filamentous stage. I shall try this again, however, when I have the means of more rapidly revolving cultures, and also of exposing stationary cultures to equal illumination on all sides. Figs. I4 and I $4 a$ show plainly, however, that the light determines which side of the thallus shall develop rhizoids, and where the illumination is approximately equal on all sides rhizoids develop on the various sides of different prothalli. Fig. I 5 shows a prothallus seven weeks after sowing on a slow clock. The prothallus is thin and expanded, though its edges are somewhat rolled, and it bears approximately equal numbers of rhizoids on its two faces. Furthermore, antheridia and archegonia develop equally on the two sides. It is perfectly possible to suppress the development of the reproductive organs of this fern by insufficient light, but when the illumination is approximately equal and is sufficient on all sides, the antheridia and archegonia develop in spite of there being no shaded side. The advantage of their developing on the shaded, usually the lower, side is evident, but the reason for their doing so is far from clear when it is possible, as just stated, to suppress their formation altogether by feeble illumination.

For one reason or another, the final and most compelling being the earth- 
quake of April 18, I have so far been prevented from carrying cylindrical plants of Anthoceros fusiformis to the fruiting stage. The spores sown earliest, on September I4, I905, were sown on slow clocks, making a complete revolution only once an hour. These clocks at first ran somewhat irregularly, stopping at times, and consequently spoiling my cultures and necessitating restarting them. More dependable means of revolving cultures than cheap clocks I expect to have in the autumn. I will record, however, that the sporophytes of this species of Anthoceros began to be of visible size about five months after sowing in cultures on the shelf. This shows that, though Anthoceros usually holds over from season to season, it can fruit during the first season from the spore, provided the rains come early enough and the winter is wet and warm enough. Fimbriaria, on the other hand, did not reach the reproductive stage in my cultures during this season, and probably requires two seasons in which to mature sufficiently to reproduce itself. Of this last I am by no means certain, however, and I shall watch the results of future experiments to determine this point.

Fig. I6 is a drawing of a plant of $A$. fusiformis nine weeks after sowing on a clock revolving the culture once an hour. This plant is drawn from above, and though presenting in general a circular outline, it is bilaterally rather than radially symmetrical. It is like those plants of Fimbriaria previously described which, growing on slow clocks, resemble both the shelf plants and those growing on faster clocks.

It is evident that only those unshaded plants near the centre of even small culture dishes, such as I have described, receive an equal amount of light from all directions. Only these plants can be expected to be and are radially symmetrical. Between the centre and the outer edge of each clock-culture the young plants are decreasingly cylindrical, increasingly dorsiventral, and those on the edge are of the usual out of door or shelf form. Furthermore, it is now especially evident why it is so important that spores must be sown sparingly; the young plants must be as remote and as nearly equidistant from each other as possible to avoid shading. Plants shaded on one side by a neighbour even near the centre of cultures on the quicker clocks are as dorsiventral as plants on the shelves. The results of equal illumination on all sides are clear and certain in all cultures of Anthoceros, but it is necessary to notice carefully that the illumination is equal for any particular plant under observation. Remote from the centre of a clock culture, or shaded by too close neighbours, or even on a slow clock, the illumination is not equal on all sides. Anthoceros appears to be less sensitive, or it reacts more promptly, than the other Archegoniates used in these experiments. This, however, I shall presently discuss.

As stated in the introduction, I have but begun experimenting on the question of the influence of the direction of light upon the form of sea-weeds, 
but I will here record the results yielded by an experiment made during a two months' stay at the Zoological Station in Naples ${ }^{1}$. Spores of Dictyopteris polypodioides were allowed to escape in sea-water in crystallizing dishes, the covers of which had sheets of black paper glued upon them. Two of these dishes were put on clock works which revolved them once an hour in a horizontal plane. The others were placed on the window shelf beside them. These spores develop at first protonema-like filaments, as Reinke showed ${ }^{2}$, on which, during the first two weeks, erect and conical buds appear. At the end of two weeks or so a flat plate begins to grow from near the top of these little balloon-like buds. This is what ordinarily happens in shelf cultures, and is presumably what happens in the sea. Fig. I 7 shows the usual young plant. On the other hand in clock cultures the course of events is decidedly different, as shown by Fig. I7 $a$. This figure was drawn from a plant at the centre of a dish on a clock, the spores being sown twenty-three days before the drawing was made. It is evident that no part of the plants had become flat, although branching had occurred. Fig. 17 indicates that, under ordinary illumination from one side only, the young plant soon sends out a branch which, growing upward, is thin, flat, and leaf-like.

Certain species of Fucus, common between the tide-marks on rocky portions of this coast, are flat and expanded. Spores of these species germinate in dishes of sea-water in the laboratory, as I know by experience. As soon as possible I shall try to cultivate these on clocks and on the shelf, and $I$ hope to follow the experiment which promised such interesting results but which was cut short by the brevity of my stay in Naples. I record the experiment here merely because the preliminary result is so consistent with the results of my experiments on land-plants, not because I think it conclusive or more than suggestive and promising.

\section{Discussion of the Influence of Light upon Form.}

The results previously described show that certain dorsiventral Archegoniates and one marine alga are more or less influenced as to their form by the direction from which the light falls upon them as they grow. This influence is most evident in the case of Anthoceros, which, whether growing on a slow clock or on one which revolves four times as fast, develops with radial instead of dorsiventral structure. All of the plants

1 The main results of my work are reported in the paper on Irritability in Algae previously referred to. In that paper I took occasion to express my grateful appreciation of the opportunity of working at one of the tables supported at the Zoological Station by the Carnegie Institution of Washington. I am glad to have this additional opportunity to thank the officers of both institutions for their help and courtesy.

${ }^{2}$ Reinke, F., Entwickelungsgeschichtliche Untersuchungen iiber die Dictyotaceen des Golfes von Neapel, Nova Acta Leopold. Acad., 1, 1878. 
experimented upon are positively phototropic, growing erect on the clocks and toward the light in the shelf-cultures. But, as Anthoceros shows, we can distinguish between the directive and the formative influence of light. It is also possible to discriminate between the influence of the direction from which the light comes, which, in a way, moulds the shape of an organism, and the influence of the quantity or intensity of light, which affects both the quantity and the kind of growth. Thus cultures too feebly illuminated contain thin, long, slender plants ('drawn,' as a horticulturist might say), which do not develop reproductive organs, though the plants may be large enough. Light, then, is a necessary stimulus to the formation of archegonia and antheridia, and light sufficient for vigorous vegetative growth may not be sufficient to stimulate plants to form reproductive organs. This, Vöchting ${ }^{1}$, Klebs ${ }^{2}$, and their followers have shown. But given the necessary quantity or intensity of light ${ }^{3}$, its direction will profoundly affect the form of a growing plant, and also the positions of the vegetative and other organs which develop upon it. This is evidently true of Anthoceros, but is not by any means so evident in the cases of Fimbriaria and Gymnogramme. Why? To answer this question we must examine the actual working of our clinostats. Unless cultures are constantly and uniformly illuminated, the plants do not receive at all times equal amounts of light on all sides. Thus, the gradually increasing light at dawn finally becomes sufficiently strong to exert a definitely stimulating influence upon the plants on which it falls. The plants are in a certain position when the light attains this degree of intensity. The revolving culture will bring them successively into all other possible positions, until finally, at the end of a quarter-hour or of an hour, according to the speed of each particular clock, they come once more into the position in which they were first stimulated by the light. The time of revolution, whether a quarter-hour or even an hour, may or may not be less than the time requisite to exert a lasting influence upon the form of the young plants. But in the morning the stimulus exerted upon any one part is followed by an equal, or even greater, stimulus exerted upon all other parts in succession, thus balancing effects on opposite sides. This is not the case at sunset. As the light fades, there comes a moment when the light still definitely stimulates a growing part, but, the moment after, the light does not stimulate the part presented to it by the revolving clock. And so it goes the night through, and till dawn again. The part last stimulated can react unopposed or unbalanced by other parts. However, if the clocks be sufficiently fast, and although the part last stimulated

1 Vöchting, H., Über den Einfluss des Lichtes auf die Gestaltung und Anlage der Blïthen, Jahrb. f. wiss. Bot., xxv, 1893 .

${ }^{2}$ Klebs, G., Die Bedingungen der Fortpflanzung bei einigen Algen und Pilzen, Jena, 1896.

${ }^{3}$ For a voluminous discussion of this topic see Mac Dougal's Influence of Light and Darkness on Growth and Development, Mem. N. Y. Bot. Gard. II, New York, I903. 
has been stimulated once more than any other part of the plant, there will be no visible evidence of this; the plant will be radial in structure, cylindrical or vase-like in form, as my Anthoceros cultures show.

This result implies two things : first, that the plants do not react very promptly to single stimuli; and, second, that the rate of revolution of the clinostat is such that no part of the plant remains exposed so long to the light that the stimulus and the reaction of any one part will not be equalled on and by all other parts. Both these conditions are realized in my cultures of Anthoceros, but not with the other two Archegoniates. The thalli of Fimbriaria and the prothalli of Gymnogramme, grown from the spore on clocks, are as dorsiventral as in shelf-cultures. This may be because the plants owe their dorsiventrality to something else than the influence of light; or, because they are more sensitive, or react more promptly to single stimuli than Anthoceros: or, because at sunset the last stimulus is sufficient to induce and fix dorsiventrality before the morning light can balance this influence.

As is well known, since Pfeffer's work on Marchantia ${ }^{1}$, dorsiventrality once induced cannot be reversed. Nor is it possible to convert one of these dorsiventral plants into a radial one ${ }^{2}$, though the change from the radial to the usual dorsiventral structure may be promptly made. Clinostats revolving faster than any which I have so far employed may show which of these possibilities is the fact, or it may be necessary to use constant approximately equal illumination from all sides. The former can be arranged, and I hope to have such experiments going by autumn. Experiments with electric lights were already in progress, and these will be resumed presently; so I hope to be able to report that, with due attention to details, experiments on these plants yield results similar to those which I have described above for two species of Anthoceros.

In speaking of the induction of dorsiventrality in the Marchantiaceae, Pfeffer ${ }^{3}$ says : 'Im näheren ist dann immer noch $z u$ entscheiden, ob die Dorsiventralität sich auch bei allseitig gleicher Beleuchtung ausbildet, $\mathrm{ob}$ also die einseitige Beleuchtung nur räumlich orientirend wirkt, oder ob sie eine unerlässliche Bedingung für die Entstehung der Dorsiventralität ist. Letzteres scheint nach Versuchen von Czapek bei Marchantia der Fall zu sein, da sich aus der Brutknospe bei allseitig gleicher Beleuchtung (auf dem Klinostaten) im Laufe von 2-3 Monaten kleine schwächliche Pflänzchen von radiärem Bau entwickelten. Aus diesen Erfahrungen würde zugleich folgen, dass in diesem Falle, wie es zu erwarten ist, das Zustandekommen der Dorsiventralität eine Bedingung für eine kräftige Entwickelung ist.'

1 Pfeffer, W., Symmetrie und specifische Wachsthumsursachen, Arb. d. bot. Inst. Würzburg,

3 Pfeffer, W., Handbuch der Pflanzenphysiologie, Bd. II, i, p. I82, I904. 
As I have shown above, equal illumination is not perfectly attained by the use of the clinostat alone. Illumination, to be equalized by a clinostat, must also be constant. This, sunlight is not. Artificial lights may be used night and day, but their composition is not altogether like that of sunlight. The use of artificial light, which I have begun, involves the question of which rays are the more potent in influencing the forms of plants. To this question I shall give attention. But, so far as my experiments have gone, it seems that the usual dorsiventrality of Anthoceros may be replaced by a remarkably regular radial structure whenever the light is made to fall, even in approximately equal strength, on all sides successively. If Anthoceros plants, started under equal illumination from the spore, can be made to grow at all in darkness, their behaviour will be very significant. If they become dorsiventral under these conditions, it would seem that the tendency to become dorsiventral is inherited, and was held in check only by abnormal illumination. If they continue to be radial and yet grow, it would seem that dorsiventrality is not inherited, but is induced by certain conditions, and it would also seem that a certain factor in the environment, the light and its direction, constitute this condition. To determine whether light from one side only is a condition merely, or is a necessary stimulus to dorsiventrality, is more difficult. This question can be answered by employing suitable artificial lights, perhaps incandescent electric bulbs of equal candle power, and so disposing them that cultures are equally lighted on opposite sides by two or by four lights. If with equal illumination on two opposite sides, the young plants are dorsiventral, Pfeffer's suggestion ${ }^{1}$ - that ' lighting from one side is a condition necessary for the development of dorsiventrality' - would seem superfluous, and that the light acts rather as a definite stimulus, the direction from which the light comes being also significant. These experiments had also been begun, but had yielded no definite results before the earthquake stopped my work.

The significance of such an investigation as this, the early results of which I have reported in the foregoing pages, consists not merely in the matters of fact thus revealed, but also in the light these facts throw on the problem of heredity. Every biologist is driven sooner or later to a contemplation of one aspect or another of this problem. The continuity of substance from parent to offspring constitutes, according to most persons, so very much the principal basis of heredity that it may almost be called the sole one in their estimation. Such biologists attempt to express in morphological or in other definite terms the means of transmitting characters from one generation to the next. Thus by chromosomes or germ-plasm or some other name the part or parts are designated to which especial importance 
is attributed. Or others, attempting to reduce the process to greater precision, would designate in terms of still smaller units-namely the chemical compounds concerned-the means of continuance of bodily characters. But since a chemical reaction depends upon the substances employed and also upon the conditions prevailing at the time, it is only where like substances act upon each other under like conditions that the results are alike. It is therefore as important to study the conditions of life as its physical basis in order to understand the phenomena of life. Analytic and experimental study of the environment will enable us, in the course of time, to reduce to definite terms of physics, as well as of chemistry, much of what is now indefinitely summed up under the name of heredity. We shall see that, along with continuity of substance, the continuity of influence must be reckoned as indispensable to heredity; that, indeed, the continuity of influence is part, and a large part, of heredity.

I have shown in the foregoing pages that, according as the direction of illumination is usual or unusual, certain plants have their normal form or some other wholly different. Whether we regard illumination from only one direction as merely a condition or as a direct stimulus to the development of dorsiventrality in Anthoceros, it is evident that, unless the young plants developing from the spore are exposed to influences like those under which their parents developed, they will be unlike their parents. So far as two species of plants are concerned I have furnished experimental evidence in favour of the hypothesis previously advanced ${ }^{1}$ that, in addition to what is actually transmitted from parents to offspring in the continuity of substance, the likeness of parents and offspring is due to the likeness (or identity) of influence to which succeeding generations are exposed. In other words, certain physical factors of the environment, constant or periodic but unchanging, constitute means of repeating parental characters generation after generation, and these environmental influences are as essentialas the substance. Given the same chemical compounds and the same arrangement of these in the fertilized egg as in the parents, the young must be like the parents if their environment is the same. But if any factor vary-in the chemical composition or in the structure of the fertilized egg, or in the conditions under which the young develop-the young will be proportionally different from the parents. The individual young will differ not only from their parents but also from each other. We are accustomed to these differences among the individuals of a brood. We are in the habit of thinking of the environment as introducing variety. The changing factors of the environment do introduce variety. So do the changing compounds or proportions of compounds in the bodies of the parents and in the fertilized eggs which

${ }^{1}$ Farmer, J. B., On stimulus and mechanism as factors in organization, The New Phytologist, ii, Nov. and Dec., I903. Peirce, G. J., Text-book of Plant Physiology, pp. 279-83, May, 1903; Certain undetermined factors in heredity and environment, Amer. Naturalist, xxxviii, April 1904. 
are the fruit of their bodies. Yet there are unchanging factors in the environment. These also contribute to the repetition of parental characters in the offspring. A knowledge of these definite forces, which we can recognize and the effects of which we can study, will help us to solve the problem of heredity.

Stanford University, California.

June, 1906.

\section{Publications Cited.}

Campbell, D. H. ('05): Mosses and ferns. 2nd Ed. New York.

CzApex, F. ('98): Weitere Beiträge zur Kenntniss der geotropischen Reizbewegungen. Jahrb. f. wiss. Bot., xxxii.

Farmer, J. B. ('03): On stimulus and mechanism as factors in organization. New Phytologist, ii, Nov. and Dec.

GaNONG, W. F. ('01) : A laboratory course in plant physiology. New York.

KLeBS, G. ('96): Die Bedingungen der Fortpflanzung bei einigen Algen und Pilzen. Jena.

MaC Dougal, D. T. ('03): Influence of light and darkness on growth and development. Mem. N. Y. Bot. Garden, II. New York.

Peirce, G. J. ('03) : Text-book of plant physiology. New York. xxxviii.

('04): Certain undetermined factors in heredity and environment. Amer. Naturalist, ('06): Anthoceros and its Nostoc colonies. Bot. Gazette, xlii, July, 1906.

Peirce, G. J., And Randolph, F. A. (05) : Studies of Irritability in Algae. Bot. Gazette, xl, 1905. Pfeffer, W. ('91): Symmetrie und specifische Wachsthumsursachen. Arb. bot. Inst. Würzburg, i. ('94): Handbuch der Pflanzenphysiologie, ii, I.

Reinke, F.: Entwickelungsgeschichtliche Untersuchungen über die Dictyotaceen des Golfes von Neapel. Nova Acta Leopold. Acad., 1, I878.

Rosenvinge, K. ('89): Influence d'agents extérieurs sur l'organisation polaire et dorsiventrale des plantes. Rev. génér. de Bot., i.

Vöchting, H. ('93) : Über den Einfluss des Lichtes auf die Gestaltung und Anlage der Blüthen. Jahrb. f. wiss. Bot., xxv.

Winkler, H. ('00): Einfluss äusserer Factoren auf die Keimung der Eier von Cystoseira barbata. Ber. d. Deutsch. Bot. Ges., xviii.

\section{EXPLANATION OF FIGURES IN PLATE XXXV.}

Illustrating Professor Peirce's Paper on Irritability in Plants.

Fig. I. Anthoceros fusiformis. Spores germinating fourteen days after sowing, light only from direction of arrow. $\times 84$.

Note direction of growth of germ-tube. Plants $a$ and $b$ shaded by others.

Fig. 2. Fimbriaria Californica. Spores germinating thirteen days after sowing, light only from direction of arrow. $\times 84$.

Note directions of germ-tube, cross-walls, and rhizoid.

Fig. 3. Fimbriaria Californica. Group of two spores at 2.15 P.M., thirteen days after sowing, light only from direction of arrow. $\times 84$.

Fig. 4. Fimbriaria Californica. Same group of two spores twenty-one hours later. $\times 84$. 
Fig. 5. Fimbriaria Californica. Germinating spore, fourteen days after sowing. $\quad \times 84$.

Note directions of growth and of cross-walls.

Fig. 6. Gymnogramme triangularis. Spores germinating under constant electric light, almost five weeks after sowing, light only from direction of arrow. $\times 300$.

Note directions of growth of germ-tubes and of cross-walls.

Fig. 7. Gymnogramme triangularis. Spores germinating on Knop's solution sixteen days after sowing, light from direction of arrow. $\times 300$.

Note directions of germ-tubes, rhizoids, and cross-walls.

Fig. 8. Gymnogramme triangularis. Diagram showing directions of rhizoids of young plants sixteen days after sowing on Knop's solution revolved on clinostat. $\times 70$.

Fig. 9. A. fusiformis. Young plant almost seven weeks after sowing on $\frac{1}{4}$ hour clinostat revolving culture of unsterilized soil. $\times 4 \mathrm{I}$.

Fig. Io. A. fusiformis. Young plant of same date ot sowing, culture receiving light from direction of arrow. $\times 4 \mathrm{I}$.

Fig. Iо a. A. fusiformis. Optical section of plant shown in Fig. Io. $\times 4 \mathrm{I}$.

Compare radial form of Fig. 9 and dorsiventrality of Figs. Io and ro $\alpha$.

Fig. II. A. Pearsoni. Young plants just over six weeks after sowing on one hour clinostat revolving culture of sterilized soil. $\times 4 \mathrm{I}$.

Fig. I I a. A. Pearsoni. Young plant of same date of sowing, culture receiving light from direction of arrow. $\times 4^{\mathrm{I}}$.

Compare this with Fig. II as to form.

Fig. I 2. Fimbriaria. Young plants almost five weeks after sowing on $\frac{\mathrm{I}}{4}$ hour clinostat. $\times 4^{\mathrm{I}}$.

Fig. I 2 . Fimbriaria. Young plant of same date of sowing, culture lighted from direction of arrow. $\times 4^{\mathrm{I}}$.

Fig. 13. Fimbriaria. Young plant $5 \frac{1}{2}$ weeks after sowing on one hour clinostat, going over to dorsiventral form. $\times 4 \mathrm{I}$.

Fig. I 4. Gymnogramme. Prothalli almost five weeks after sowing on $\frac{\mathrm{I}}{4}$ hour clinostat. $\times 4^{\mathrm{I}}$.

Fig. I4a. Gymnogramme. Prothalli of same date of sowing, culture receiving light from direction of arrow. $\times 4 \mathrm{I}$.

Fig. I5. Gymnogramme. Prothallus seven weeks after sowing on one hour clinostat. $\times 4 \mathrm{I}$.

Rhizoids and reproductive organs on both sides.

Fig. I6. A. fusiformis. Young plant almost nine weeks after sowing on one hour clinostat. $\times 4$ I.

Note half-round form on slow clock.

Fig. I7. Dictyopteris polypodioides. Young plant in dish of sea-water on shelf, receiving light from one side only. $\times$ I 25 .

Fig. I7 a. Dictyopteris polypodioides. Young plant twenty-three days after sowing in sea-water on one hour clinostat. $\times 125$. 
Annals of Botany.

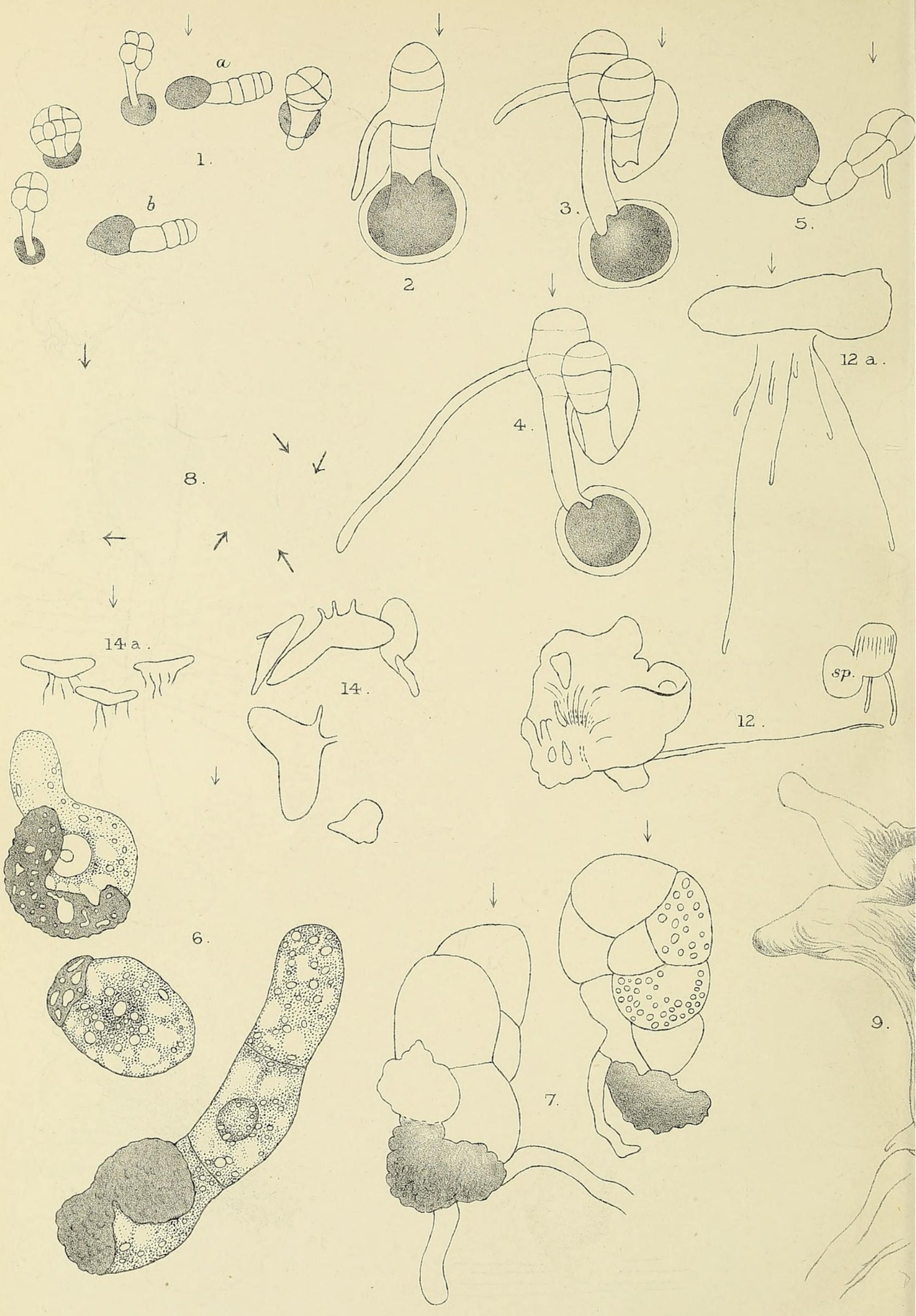

G.J.P. de]

PEIRCE - FORMATIVE INFLUENCE OF LIGHT. 
Vol.XX. PL.XXXV.
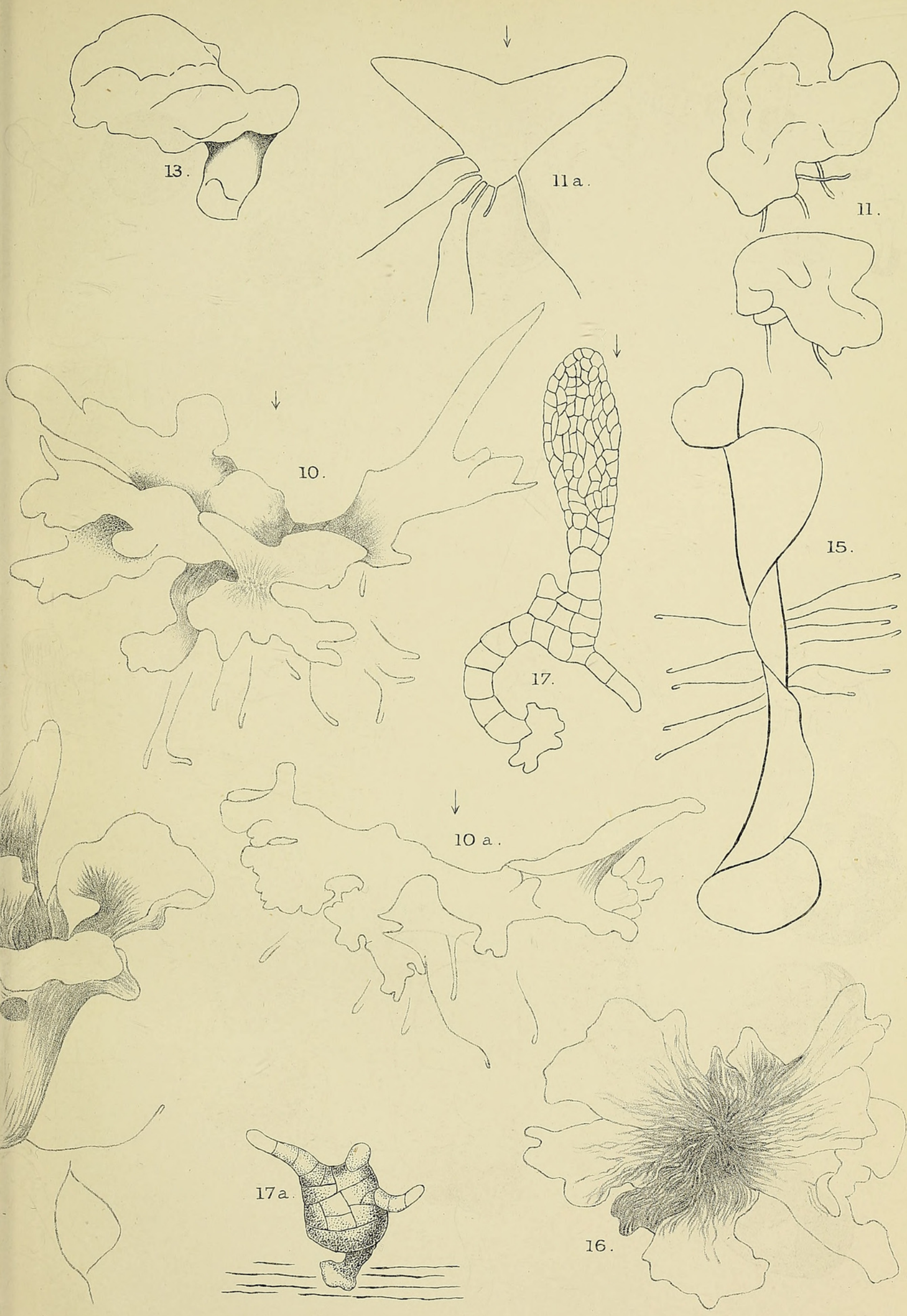

Huth, lith. et imp 


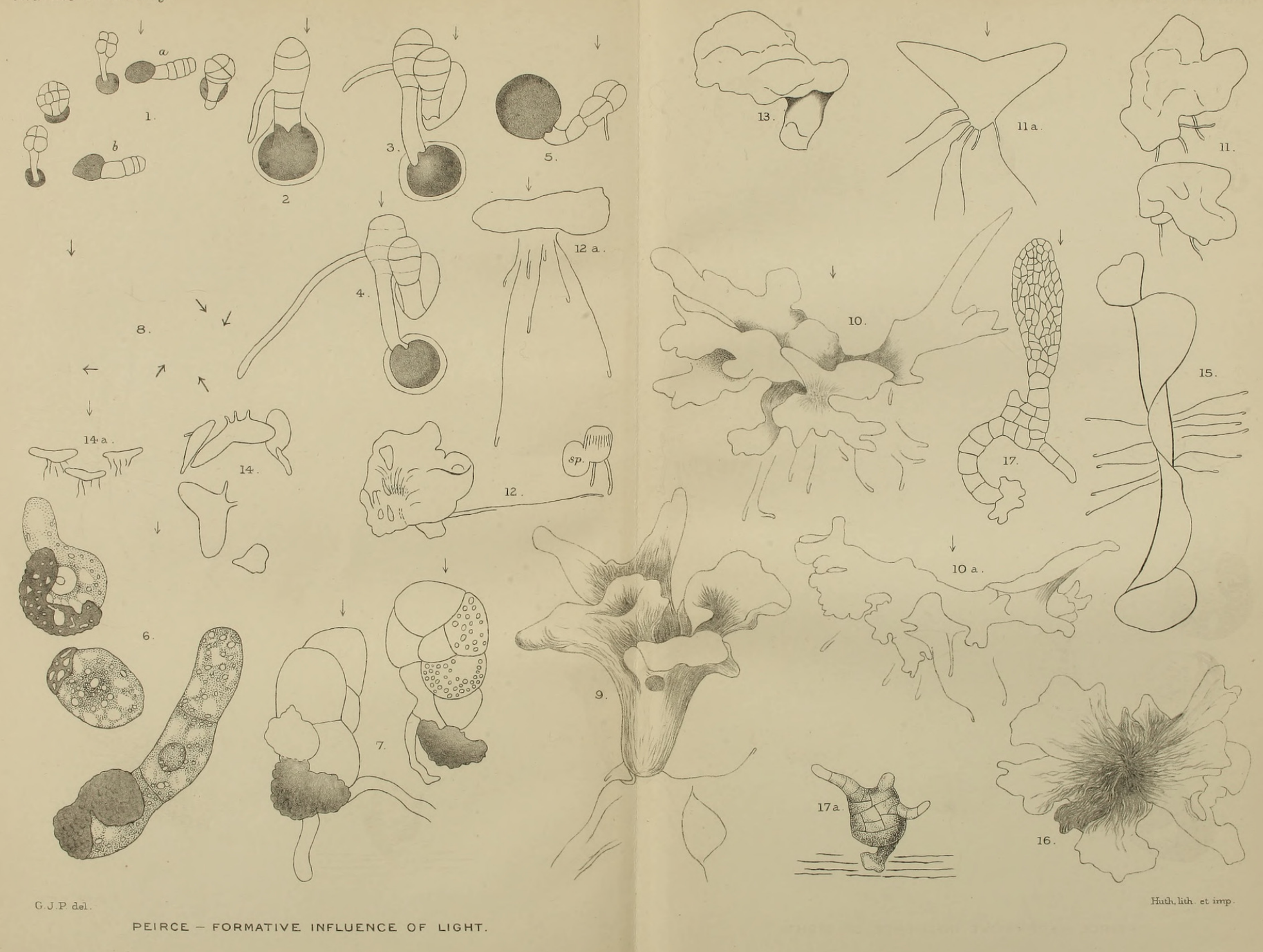




\section{$2 \mathrm{BHL}$ Biodiversity Heritage Library}

Peirce, George James. 1906. "Studies of irritability in plants." Annals of botany 20, 449-465. https://doi.org/10.1093/oxfordjournals.aob.a089113.

View This Item Online: https://www.biodiversitylibrary.org/item/234848

DOI: https://doi.org/10.1093/oxfordjournals.aob.a089113

Permalink: https://www.biodiversitylibrary.org/partpdf/318853

\section{Holding Institution}

Smithsonian Libraries

\section{Sponsored by}

Biodiversity Heritage Library

\section{Copyright \& Reuse}

Copyright Status: Not in copyright. The BHL knows of no copyright restrictions on this item.

This document was created from content at the Biodiversity Heritage Library, the world's largest open access digital library for biodiversity literature and archives. Visit BHL at https://www.biodiversitylibrary.org. 